This is the version of the article accepted for publication in Third World Thematics: A TWQ

Journal published by Taylor \& Francis: https://doi.org/10.1080/23802014.2018.1502048

Accepted version downloaded from SOAS Research Online: http://eprints.soas.ac.uk/26238

\title{
Boundary Anxieties and Infrastructures of Violence: Somali Identity in Post-Westgate Kenya
}

\author{
Awino Okech, Lecturer, Centre for Gender Studies
}

Email: ao21@soas.ac.uk

\begin{abstract}
:
This article explores infrastructures of violence created by ongoing contestations around (in) security related to violent insurgency in Kenya. It draws on public discourses and policy responses emerging from the September 2013 terror attack at Westgate in Nairobi, Kenya. By exploring the connection between public discourses on resolving (in) security, this article explores the security policies developed to cordon off particular geographical sites and construct Kenyan Somalis as the "other" ostensibly to secure the country. I argue that security discourses and resultant policies produce fluid security infrastructures. This is evident in a move from a focus on physical security infrastructure evident in "boots on the ground" and visible security sector presence, to less visible forms of security which rely to a great extent on surveillance both by the state and citizens.

\section{Biographical Note:}

Dr. Awino Okech's teaching and research interests lies in the nexus between gender, sexuality and nation/state making projects as they occur in conflict and post-conflict societies. Prior to her appointment at the Centre for Gender Studies, she contributed to knowledge production and transfer through an adjunct teaching position with the African Leadership Centre at Kings College London.
\end{abstract}

Key words: Gender, Extremism, Masculinities, Security, Kenya, Al Shabaab

\section{Introduction}

This article emerges out of an interest in what debates about countering violent extremism do in societies managing contested national governance transitions. I explore how terror has been deployed as a lexicon by political elites to manage a range of governance demands from citizens. Specifically, I focus on the role that discourses on violent extremism have played in the development of security policies that have cordoned off specific geographical zones in the city 
and/or discursively produced Kenyan Somalis as the "other" and therefore targets for securitization. In this regard, I am interested in the gender and class dynamics that produce criminalised and securitised masculinities. Security policies form part of mobile infrastructure thus moving attention away from only paying attention to the physical presence of security forces in fixed geographical spaces that then construct boundaries of (in)security. In focusing on mobile infrastructure, I engage the policy responses that discursively deploy various forms of surveillance as a key feature of this mobility and generate gendered targets of said surveillance. Kenya offers useful examples to unpack the ways in which the current regime creates sites of concentrated violence by security forces. My analysis is limited to the period 2013 - 2015, with 2013 marking the year when the Westgate terror attack occurred ushering in a range of security related discussions in the public domain that came resulted in a number of policy responses between 2014 and 2015. Due to my interest in discourses, I draw predominantly on secondary sources for my analysis. Chief among these sources is data generated from two social media hashtags referred to later in this article, analysis of speeches by President Uhuru Kenyatta on security between 2013 2015 and parliamentary Hansards that cover debates on terrorism. Ultimately, I am interested in how the speech acts by the President result in specific policy responses that define the Somali community and a geographical zone predominantly occupied by them as a securitisation target.

This article begins by exploring the historical manifestations of violent extremism in Kenya and the accompanying militarization in the wake of a specific terror event. Secondly, I am interested in drawing on the political uncertainties that Kenya has experienced in the period between 2013 - 2015 to understand the role that the threat of violent extremism has played in reconfiguring Somali identity and therein Somali masculinities. Kenya offers an opportunity to unpack the nexus between violent extremism, democratic reconsolidation processes and the production of militarised ruling masculinities and securitized subordinated masculinities in general. In reflecting on gender, this article pays attention to the contested forms of male-ness that have been produced by the dynamics post the Westgate terror attack. I am cognizant that gender is co-constitutive, which means there are specific ramifications for nonmale people, specifically women, though this is not the focus of the article. This article analyses masculinity in the heteronormative ways in which it manifests in discussions on securitisation of Somali men in Kenya. While there is an opportunity to challenge how hetero-patriarchy is taken as given and which therefore reinforces performances of ruling masculinity, this does not fall within the scope of this article and is therefore not explored. 


\section{Conceptual Notes}

This article draws on two main conceptual frameworks to respond to the questions above. The first framework is an extension of the work of Mary Douglas $^{1}$ on boundaries and embodiment. In this article, I used boundaries in two ways. The first way is to refer to the physical markers of boundaries across territories which are evident in infrastructure such as railway lines that divide industry (the workers) and sites of capital (those who manage the money) and therefore the people who cut across these divides on a daily basis ${ }^{2}$. The roads (poorly constructed and badly networked) and/or under-developed public transport systems determine how people negotiate the city for employment and living arrangements. Like other major cities across the globe, these boundaries across city landscapes are racialised and serve as a key marker of class distinctions. Consequently, the geographical landscapes that arise out of physical infrastructure offer a master narrative of a place. Geographical landscapes define what is inscribed as official memory, which is often represented through development plans and visions. Underlying the master narrative is evidence of anxiety about managing boundary porosity, which is linked to policing bodies that are perceived as likely to "pollute" the zones that are being safeguarded. Couched in developmental language around progress and managing poverty, zoning, housing and security arrangements are created but they silence the oftviolent ways in which these forms of progress are experienced by those on the periphery.

The notion of porosity is linked to the second way I use boundary and that is through a focus on gendered bodies. In this regard, I am interested in Douglas's ideas about purity and danger. Douglas constructs the body as a complex structure, asserting that the power and danger credited to social structures of power are reproduced on the human body ${ }^{3}$. I draw on Douglas ideas on porosity of bodies and danger for my analysis of Kenya by focusing on the discursive production of Somali masculinities as dangerous. Yuval Davis and Kandiyoti note that when societies are at threat due to war or conflict, the management of death and life during war or peace rests on managing ideas about femininity and masculinity ${ }^{4}$. Douglas suggests that whenever lines of security are precarious, such as those that offer the potential to collapse notions of shared national or community identity, discourses about pollution come to the support of those claiming their own identities against 'others'5. I extend Douglas analysis by examining how death and incarceration become rituals through which political regimes manage pollution and "purify" societies of dangerous and contagious populations. The boundary anxiety produced by the need to manage porous bodies ostensibly to produce a stable Kenyan in the light of the threat both real and perceived of violent extremism is key to my analysis. 
My analysis of purity, porosity and danger is complemented by Kopano Ratele's concept of ruling masculinity. ${ }^{6}$ Ratele's work on understanding males who are powerless in relation to other males but are members of a powerful group in the context of hetero-patriarchy is useful to my examination of Somali masculinities in Kenya. Ratele uses the categories of age and income, which I will draw on, as a basis to examine the relationship of non-hegemonic males to reigning ideas of male-ness. In this case, this article examines young Somali men's relationships to security actors and the Kenyan regime. Using space and time this article examines the evolution of young Somali men's relationship to various Kenyan regimes. This article analyses how the construction of nonhegemonic ruling masculinity is constructed through securitised discourses of Somalis as a community and often visualized through Somali male youth. The construction of hegemonic masculinity through both speech acts and performances of military leadership through the incumbent president are designed to project safety and strength, at the same time that Somali masculinities are subordinated and securitised along age, class and racialized lines in the country.

The construction of masculinities and how these are mobilized to manage the danger associated with porosity of boundaries as articulated above is anchored on Buzan's work on securitization. In this article I draw on two aspects of securitisation theory, the first is the central argument that connects speech acts by a security actor to their ability to claim a right to extraordinary measures to tackle an issue thus moving it out of the realm of normal politics into an extraordinary realm of political procedure ${ }^{7}$. For Kenya, the evolution of violent extremism policy responses and public discourse around it can be traced to speech acts of the President most notably those which launched Kenya's military incursion into Somalia in 2011 ostensibly to "protect Kenya". However, this article is concerned with the escalation of regime responses to violent extremism since 2013, that have relied on arguing for normal rules and regulations of law and policy making to be side stepped to enable an effective Executive response. ${ }^{8}$ This article does not suggest that terrorism is not a self-evident security concern, rather, securitization theory draws attention to the exceptionality attached to a securitization move, which results in a shift in "business as usual" when dealing with the issue that is securitised. It is the consequences of the suspension in rules due to securitization on a specific section of Kenyans that this article examines. Here Huysmans's expansion of securitization to an examination of practices and devices becomes important to how I think about securitization beyond the discursive? .

The second component of securitization that is essential to the analysis in this article is the notion of societal security, which is when societies perceive threats in identity terms. Buzan identifies the process of establishing the "other" 
as essential to the construction of an identity based threat ${ }^{10}$. Waever asserts that in the absence of the "other" one cannot speak about security. Therefore, societal securitisation is rooted in the identity politics of self and "other", with the enemy-other often identified as another society or an ethnic group, and the security of one means insecurity of the other ${ }^{11}$. Consequently, societal survival may be sought at expense of others, particularly when "others" are presented as an existential threat to a society's identity. In linking the two articulations of securitization above, this article argues that the securitization move made to deal with terrorism in Kenya, provided cause for the regime to exercise extraordinary security measures, which in this case was accompanied by societal securitization of the Somali community. The process of securitizing the Somali as a community can be traced to the creation of boundaries for security operations, which collide with areas predominantly occupied by Somali Kenyans. In addition, through speech acts of the President and influential politicians allied to the current Kenyan regime, a direct link is made between Somali identity and terror thus legitimizing in some quarters the securitization of this community. In this article, I make a connection between Buzan and Waever's ideas of societal securitization to Douglas conceptualization of boundary anxieties. Douglas thinks about boundary anxieties as generated by societal threats being mapped onto gendered bodies that are considered porous and therefore risky. Ratele's analysis of masculinities extend the gendered analysis of porosity and danger developed by Douglas to assess the implications of Somali societal securitisation on the production of masculinities.

\section{Geographies of Violence}

On $1^{\text {st }}$ April 2017, a cellphone video was circulated across most Kenyan social networking sites ${ }^{12}$. In it, a plain clothes policeman is captured confronting and shooting an unarmed man, who appears roughed up since his clothes are half torn and he is bleeding. All of this occurs in front of a crowd of onlookers. The shooter appears undisturbed by his audience as he stops to get another loaded gun from a man we assume to be a police officer before firing the bullet that eventually kills the man who is lying on the ground. Within the video frame lies another dead body that a viewer can assume was a victim of extra-judicial killing by the same officer. It is evident that the person recording these deaths is conscious of the (in) dignity of the public spectacle surrounding these murders because they zoom out when the shots are fired. These deaths occurred in Eastleigh, Nairobi. After initially challenging the authenticity of the video, the Kenyan police service eventually confirmed that the executioner was a police officer and the two young men were apparently members of a well-known criminal gang ${ }^{13}$.

This example illustrates the ways in which specific geographical areas in Kenya have become sites for normalized security operations. The logic of this 
normalization is rooted in a political environment in which the securitization of terror has enabled cordoning of specific sites and therefore communities as legitimate targets of security based harassment. National security concerns generated by violent extremism provide room for the justification of extrajudicial killings, publicly articulated as evidence of a regime in charge of security matters. ${ }^{14}$ The construction of Eastleigh as it emerges in discussions on terror in Kenya as a hub for terrorists leads to the justification of certain "security" actions as plausible in this area without attention to the rule of law. The rationale for Eastleigh as a "free zone" for extra-judicial security action is anchored in its construction as a porous geographical location that needs to be securitised in order to be effectively brought under "Kenyan" control. In addition, the securitization of Eastleigh is connected to the regime linking the "danger" in it to one associated with the porosity of Somali identity in Kenya. This dual construction of the site Eastleigh and Somali societal identity as requiring securitisation has been bolstered by speech acts by security officials who draw their mandate from Presidential direction that construct Somalis as "other" foreigners, illegal immigrants, refugees. ${ }^{15}$

The porosity and danger associated with Somali identity in Kenya is not a 2013 occurrence, there are historical antecedents located in Kenya's complicated colonial and post-colonial history with Somali Kenyans. In sum, these are located in two processes, the frustration of historical efforts to pursue a greater Pan Somali vision that sought to unite Somali occupied zones and an accompanying process of socio-economic and political exclusion by both the colonial and postcolonial regimes. At the beginning of the Lancaster House talks on Kenya's independence Constitution, a delegation of Somali leaders stated their desire to have NFD secede to Somalia to join the Greater Somalia, which would encompass all those areas in which people of Somali origin were found. Greater Somalia would therefore span Somalia, Somaliland, Ogaden in Ethiopia, North Eastern Kenya and Djibouti ${ }^{16}$.

While the desire to create a Pan Somali region emerged from the havoc that arbitrary and artificial colonial arrangements wreaked in Africa, it was also exacerbated by the exclusion and under-development that framed the Northern Frontier District (NFD) as it was called then. The British colonial government approached the NFD as an area that needed to be circumscribed by instituting the Outlying District Ordinance of 1902, which restricted both residents' movement and the relationship of the centre - Nairobi. Additional legislation, which included, the Special Districts (Administration) Ordinance of 1934 and the Stock Theft and Produce Ordinance of 1933, gave colonial administrators extensive powers of arrest, restraint, detention, and seizure of property of 'hostile tribes'17. Jomo Kenyatta's post-independence regime sustained the use of draconian colonial laws in addition to new legislation that gave power to rule the 
region by decree and enlarged emergency powers. The government imposed emergency rule in the region that led to decades of state harassment, which included Somali leaders being routinely placed in extended 'preventive detention', the creation of protected villages and continued restriction of entry and exit into the region ${ }^{18}$. The post-Kenyatta regime did not alter the status quo. In November 1980, government authorities massacred approximately 3000 ethnic Somalis of Bulla Kartasi and around 5000 of the Degodia Somali sub-clan were killed at Wagalla airstrip in February 1984, in what is now known as the Wagalla Massacre ${ }^{19}$ Emergency laws governing the region were only lifted in 1992, the same year that ushered a return to multi-party democracy after close to thirty years of a single party regime by Kenyatta and later Daniel Moi. The construction of Somalis in particular as shiftas - bandits, militias, means that the state inscribed in law and practice that this was a community that would be subject to exceptional rules, with limited legibility as citizens.

The impact of the historical juridical and de facto segregation of North Eastern Kenya has had specific ramifications for the relationship between extremist insurgency, exclusion and boundary control. One of the persistent complaints from residents in North Eastern Kenya concerns the difficulties associated with acquiring national identity cards, which has relied on extra vetting of residents of the region. While specific data is hard to come by, anecdotal evidence suggests that those with Islamic names generally requiring additional rigorous vetting in order to acquire identity cards than those with Kenyan or European names ${ }^{20}$. The insistence on vetting Somalis as a security measure has created room for corruption since government authorities rely on local elders to determine the authenticity of the claimants, a process that is open to manipulation ${ }^{21}$. These historical exclusionary approaches re-surfaced as part of a broader security narrative around managing the extremist group Al Shabaab in the Horn of Africa. The security narrative reproduced in public discourses position Somali Kenyans as refugees, foreigners, criminals, the source of Islamic radicalization and $\mathrm{Al}$ Shabaab recruitment. ${ }^{22}$ However, state absence has provided room for radical groups such as Al Shabaab to mobilize exclusion its advantage.

The rise of Al Shabaab in particular, can be traced to the forced dissolution of the Islamic Courts Union in Somalia in 2007 as part of a longer trajectory of state fragility informed by a range of military interventions over the last two decades. ${ }^{23}$ Due to its proximity, Kenya has felt the impact of Somali's state fragility and has played the role of a host nation for fleeing Somali citizens. There are subsidiary impact factors such as the flow of small arms and light weapons into the country due to weak boundary management, but central to this article is Kenya's history as an American ally that has resulted in a long list of collateral terror attacks by various extremist groups as far back as the well 
publicised attack on the American embassy in Nairobi in August 199824. In 2011, Kenya launched a military operation in Somalia called Operation Linda Nchi (protect the country) was framed as an effort to secure Kenya's borders and territorial integrity. The military operation was informed by an increase in $\mathrm{Al}$ Shabaab attacks on bars in downtown Nairobi, to crowded bus termini and churches with the majority of their casualties and targets have been civilians at $25.9 \%$ with military targets constituting $22.4 \% .{ }^{25}$ However, in framing $\mathrm{Al}$ Shabaab's access to Kenya as externally generated in Somalia, the Kenyan regime ignored the existence of sleeper cells in Kenya, which has led to an increase in local radicalization rather than an overt Al Shabaab presence. An expansion in youth radicalization to include Kenyans of non-Somali descent draws attention to broader socio-economic inequalities. ${ }^{26}$ In addition, the trends in youth radicalization evident in the presence of sleeper cells in Kenya also highlight the danger that is erroneously mapped on Somali bodies thereby erasing broader discontent in the country ${ }^{27}$.

\section{Re-defining security boundaries}

"Security is a shared mandate of all people living in Kenya. The first rule of security is vigilance" - President Kenyatta.

The September 2013 Westgate mall attack in Kenya, was considered significant in comparison to previous Al Shabaab claimed attacks, largely due to its target an upmarket mall, that epitomised the convergence of economic and political elite interests, given that a number of political leaders had relatives in the mall during the attack, some of whom died ${ }^{28}$. The mall was also symbolic of freedom and prosperity associated with neo-liberal economic development rhetoric, the free market, hard work, entrepreneurship, global citizenship and aspiration as the core drivers of change that will upset inequality. The symbolic and economic factors that define what Westgate stood for are critical to how the responses to the terror attack evolved into a geographical, class based response to defining extremists and their sites of operation.

Kenyans who frequented the mall performed equality because it was a place of aspiration. Yet, Westgate in effect represented the class divide created by capital given its location across the city in an area associated with the up and coming middle class. In addition, its employees were largely young people from low income families living on either side of the highway - Waiyaki way - east of Nairobi or the West of it. Socio-economic inequalities lead to various manifestations of contradictory gendered (in) security, which are sustained by an underlying hetero-patriarchal system. For instance, the stark reality that women and men will navigate physical spaces based on different bodily autonomy threats even where class positions are shared. The fact that public 
transport systems are unsafe spaces for women and this is heightened depending on the time of the day yet income inequalities demand vast travel distances across the city for employment heightens precarious work conditions as well as greater exit for women out of employment arrangements such as wait staff jobs thus increasing women's income inequality. ${ }^{29}$ The Westgate attack therefore became a pivotal moment in shaping debates on national security and the accompanying infrastructure despite the fact that Kenya's history with terror related attacks goes back to a 1975 bus park attack. ${ }^{30}$

When it became evident that the attack at Westgate was not a violent robbery gone wrong but a deliberate attack by individuals allied to Al Shabaab, a number of discursive tropes emerged that begun to build a rationale for carving out specific geographical locations as targets for state violence. There are two that I want to focus on. The first trope, was the immediate effort to corral unity through the hashtag \#WeAreOne on Twitter and its use to rally a Nairobi based blood drive due to the large number of victims. Accompanying the hashtag was the use of the flag and the city-scape as symbol of unity. Through the blood drive citizens mobilized the idea of a unified nation- state and therefore used grief and tragedy to erase albeit temporarily the fact Kenya before Westgate was a country struggling with a range of socio-economic and political inequalities ${ }^{31}$. The symbolism of blood during this period can also be viewed as part of a process of re-purifying the porous Kenyan borders tainted by the Al Shabaab attack thus reconsolidating a national identity. However, the Westgate tragedy corralled a false unity, by constructing an "us" versus "them". The discursive mobilization of a united Kenya through the social media hashtag \#WeAreOne and its translation into action through a massive blood drive, food donations and free counseling support for survivors of the attack was an essential part of creating a broader national psyche that facilitated an acceptance of the suspension of the rule of law when it came to the policy options in response to terror ${ }^{32}$. I argue that an acquiescence to a suspension in the rule of law was only in some sections of the Kenyan public. The debate generated under the hashtag \#KasaraniConcentrationCamp and the counter-advocacy that emerged from it as a direct response to the extraordinary measures taken by the regime will be explored in the section that follows. The regime's policy responses demonstrated that this was not only the securitisation of terror but also the securitisation of an identity- Somali identity.

\section{Nationalism and Securitisation Policies}

The historical legacies of a securitized community as explored earlier in this article found continuity post-Westgate in two specific policy responses that led to the continued discursive production of Somali identity as one that needed to be securitized through boundary management. These policy responses are 
Operation Usalama Watch that led to \#KasaraniConcentrationCamp and the Security (Amendment) Laws 2014. Securitization of Somali identity through the boundary management of Eastleigh manifested in the surveillance of Somali men and the production of Somali masculinities as distinctly linked to terror. This section illustrates the ways in which policy followed geographical boundaries and was linked to othering a community. I bring together Buzan and Waever's ideas on the securitization of a society ${ }^{33}$, Douglas articulation of gendered bodies becoming containers for the construction of porosity and danger and the physical construction of threat boundaries as evidenced by the geographical specificity of both operations. Finally, Ratele's conceptualisation of nonhegemonic masculinities connects class, race and age to the construction of Somali masculinities emerging from the security policies implemented in areas predominantly occupied by Somalis.

In thinking about the connection between speech acts and policy, it is critical to point out that the process of developing policies is by no means linear. A rational choice approach to policy making ${ }^{34}$ has long since been debunked given that multiple interests influence the policy making process at any given time. This is further complicated when it comes to security policies since most of these decisions lie with institutions whose operations lie outside public scrutiny. For instance, the National Security Council is the key decision making organ on security in Kenya with its membership and deliberations are highly restricted. This background is critical to locating the speech acts and resultant policy positions explored in this section. The central point is that these statements cannot be read on their own but must be understood within a larger policy making environment in which both internal and external actors influence decisions. Second, the excerpts examined below from a presidential speech, a parliamentary discussion and the outcomes of a joint parliamentary committee report represent only part of the picture and are not in any way indicative of a linear decision making process and/or a comprehensive overview of the multiplicity of debates on the subject. What these excerpts do for the purposes of this article is illustrate certain patterns associated with the identification of the sites of security threats and the arrogation of additional power to specific institutions.

The first excerpt below is taken from a speech by President Kenyatta on the evening of $21^{\text {st }}$ September 2013 as the Westgate attack unfolded in Nairobi. The second excerpt is from a 2013 joint parliamentary committee set up to investigate security operations at Westgate and provide recommendations on how to improve the country's security response to emergencies and terrorist attacks. While both are self-explanatory, the first excerpt below alludes to the discretionary measures taken by the Executive to empower the security agencies to act decisively on matters related to terror and others so long as they were perceived as a security threat. Using the Westgate terror attack, the President 
side stepped the oversight and accountability mechanisms created after the 2008 post-election crisis which were designed to reform the police service that historically exercised power extra-judicially to the detriment of human rights ${ }^{35}$.

I have directed security agencies to be decisive in their response to this or any other threat. They must and will do this to demonstrate our constitution's categorical guarantee of Kenyans' indivisible rights to life and property. Across the country, we have tightened security but I urge all of you to remain calm and vigilant ${ }^{36}$ - President Uhuru Kenyatta, $21^{\text {st }}$ September 2013

The security directive of the President above post Westgate in addition to the national effect of the terror attack generated Parliamentary debate about accountability and a "stronger" security response. A Joint parliamentary committee was tasked with investigating the security response to the attack ostensibly to ensure that security loopholes were sealed and individuals held responsible. These investigations led to the head of the intelligence service resigning. While the findings of the committee illustrated in part below were contested by Kenyans ${ }^{37}$, the report was adopted and its findings found home in a series of policy directions that were later reported on in the President's state of the nation address, in the section that follows ${ }^{38}$.

Declaring war against Al Shabaab wherever they are. That the war against terrorism should be intensified within and outside the country. Investigating lapses in the country's security agencies. Radical surgery in the Department of Immigration Services as well as holding the Department of Immigration Services, the Registration of Persons Department, the National Registration Bureau and the Department of Refugee Affairs accountable for compromising national security. Repealing of the Refugee Act of $2006^{39}$ - Joint Parliamentary Committee Report, December, 2013

There is a connection between the Executive and the role of parliament in cushioning the Executive's decision in legislative might. The fact that the regime had a majority in parliament cannot be under-estimated here for its mobilisation power. The recommendations from the parliamentary report are critical here because their broad framing facilitated the Security Laws amendments and Usalama Watch. Additionally, the parliamentary report findings created room for the commencement of construction of a wall on the border of Somali and Kenya, attempts to close the oldest and largest refugee camp in Kenya - Dadaab, and a crackdown on a Somali owned international money transfer system Dahaabshil which continued the larger surveillance of Somalis ${ }^{40}$.

\section{Identity and Boundaries: Eastleigh and Somali-ness}

The ground for Operation Usalama Watch and the Security (Amendment) 
Laws, 2014 was laid in the President's state of the nation address in 2014, excerpts below.

Last year's evil terrorist attack, among the worst in Kenyan history, forcefully reminded us of these facts. I stood before the nation, and vowed that we would not be cowed or divided. Our response was firm, without threatening the bonds of brotherhood that hold between our different faiths. Under extreme provocation, the unity of the nation was preserved. My government has laid a firm base for the protection of our people and their property. [...] My government has also invested heavily in surveillance equipment, and at least 1200 vehicles for our police. We will also substantially increase police numbers, which have already significantly progressed from one police officer for 750 citizens to1:535. These, and more, will be underpinned by the most extensive new investment in security since independence. My government will allocate resources adequate to the needs of our security agencies, the better to modernise them, and enable them meet current and emerging threats to our safety - Uhuru Kenyatta, State of the Nation address, March $2014^{41}$

On April 5, 2014, 6,000 police were deployed to Nairobi's Eastleigh neighborhood to "arrest foreign nationals who were in the country unlawfully and anyone suspected of terrorist links" 42 . This operation was called Operation Usalama (safety) Watch. The security operation predominantly affected Somalis, Somali Kenyans, Ethiopians, South Sudanese, and Kenyan Muslim population. About 1,000 Somalis were arrested in a two-day police operation in Nairobi's Eastleigh suburb and were taken to Kasarani Stadium outside Nairobi. ${ }^{43}$ The operation, which was authorised by President Uhuru Kenyatta was aimed at "cleaning up" Eastleigh of illegal immigrants ${ }^{44}$. In the process, the government reprised the historical narrative that associated terror and illegality to Somali identity. Cleaning up Eastleigh was intimately connected to the notion of porosity and purity. Porosity in connection to physical boundaries and the inability to track the movement of Somali citizens in particular because of the existence of a Somali-Kenyan community. Tracking Somalis is not only linked to larger nation-state conversations about managing boundaries and migration but is also about security risks associated with the protracted conflict in Somalia. Combined with the border porosity, the Somali nation's impurity was also linked to the associative "stain" of Al Shabaab. Patriotism was therefore mobilized to ascertain cleanliness and entrench citizen-led surveillance as a way to secure the country. Good Somali's versus bad Somalis. Kenyan-Somalis versus the "others" were evident in the proof sought by security personnel.

The police used a language test to distinguish the good Somalis from the "bad Somalis" - bad Somalis here are those in the country illegally, refugees living outside refugee camps and Al Shabaab sympathisers. The police argued that the ability to speak Kiswahili was a good indicator of Kenyan-ness, thus 
serving as a cleaning mechanism ${ }^{45}$. The use of Kiswahili as a screening mechanism resulted in many Somali women being held as illegal immigrants ${ }^{46}$. This approach demonstrated how such tests ignore the ways in which immigrant communities or those who are under siege rely on distinct gendered public/private binaries to retain notions of nation-hood and identity ${ }^{47}$. In these cases, the domestic home-making sphere is occupied by women and the public, employment and economic space is occupied by men. In addition, language as a screening approach also ignored the nature of Eastleigh as a space within which the Somali community in particular has re-forged national identity in the face of state surveillance. ${ }^{48}$ The re-constitution of Somali identity is linked to the extra vetting required of Somalis in order to acquire national identity cards ${ }^{49}$. An identity card represents 'proof' of Kenyan citizenship without which an individual cannot vote, purchase property, access higher education or even obtain employment. For Somali Kenyans, the precarious relationship of belonging with the Kenyan state has led to Kiswahili being understood as a language of trade and not one that defines belonging. Underlying the mobilization of the knowledge of Kiswahili as proof of distinction between Somali-Kenyans and Somalis, the police were also corralling the idea of intermarriage as an important way of demonstrating assimilation in Kenya. Intermarriage with "locals" - the authentic Kenyans would ensure Kiswahili uptake and consequently reduce the danger of Somali community ${ }^{50}$. Through inter-marriage the danger posed by Somali identity would be purified by blood (children) rituals. Whether it is Somalis marrying in or Kenyans "marrying out", women's reproductive capacities are mobilised to manage porosity of Somali identities that were now framed as dangerous in light of violent extremism.

The notion of marriage and purity generated a heightened sense of nationalism that was critical to the distinction between "us" from "them". Family values were key to screening in Usalama Watch through notions of marriage and child birth in addition to providing space to centre women's maternal role in national efforts to countering violent extremism. In doing so, these programmes emphasized the Somali woman's role as a mother, as influencers and community peacebuilders within the domestic sphere. ${ }^{51}$ The sphere of engagement was distinct, with men tasked to engage religious leaders whilst the women were asked to provide tighter surveillance of their son's movements ${ }^{52}$. So even where efforts are made to recognise women's agency, women get re-centered as mothers whose role in the domestic sphere is more important to prevention, rather than a willingness to engage the factors that are shaping the increased radicalisation of young women. In addition, the focus on women through the restrictive boundaries of domesticity leads to new recruits to extremist groups being considered an anomaly, which means that women as active agents in extremist groups are ignored 53 . 
Finally, if the operation alone did not demonstrate the geographical and communal specificity, public conversations under the hashtag \#KasaraniConcentrationCamp illustrated how Somali masculinities were being redefined in the face of terrorism. \#KasaraniConcentrationCamp emerged out of events reports under Operation Usalama Watch in social and mainstream media, particularly when it became apparent that hundreds of Somalis were being rounded up and held illegally at the Kasarani Sports Stadium ${ }^{54}$. The debates under this hashtag revealed the convergence between the securitization of terror being leveraged to securitise a community. The argument that refugees and out of status residents could only be resident in Eastleigh thus providing a rationale for this targeted security operation, played into the historical exclusion that has traditionally labelled Somalis as external and othered in the Kenyan state. The mobilization of the imagery of a concentration camp in social media served the function of highlighting the illegality of the state's security operation. It was also a reminder of the suspension of legality where Somalis as a community are concerned through 1960s emergency laws that allowed security officials to act outside the rule of law ${ }^{55}$. Additionally, the images of the holding cells in makeshift cages also drew attention to the existential threat now facing a community under the guise of fighting terror ${ }^{56}$. In securitizing Somali identity through security policies developed due to terror, the Kenyan state positioned itself as the other - in relation to the Somali self which was at threat. Sections of the Kenyan public considered the regime's actions legitimate because it was seen as evidence of "taking charge" of a greater, national security threat ${ }^{57}$. An excerpt from a parliamentary debate on the nature of the regime's responses to terror illustrates this desire for decisive action from the government:

I want us to borrow from the US experience. Congress rallied around President Bush notwithstanding political affiliations. I want to challenge this House: Let us rally around the Commander-In-Chief. However, let me also challenge the Commander-In-Chief: Come to this House with some very bold measures which can enable us to hand you full authority to deploy the full arsenal of the Commander-In- Chief, including zone declaration of state of emergency. We can zone this country and identify places that must be placed under special attention and special action. As we do that, I hope that hon. Members of this House will not go out there, if your constituency is among the special zones, to start screaming: "My people are being finished." This is not about your people. This is about Kenya and security. - Ababu Namwamba, MP. 14th April $2015^{58}$

\section{Gendered Bodies and the Logic of Violence}

The underlying logic of violence illustrated above was one that linked it to ensuring security and was also evident in the carte blanche given to the police by the regime to deal with "terrorists". This arrogation of power is grounded in the 
securitisation move that led to a suspension of rules in order to deal with this new security challenge. The suspension of rules in Kenya's case occurred through amendments in laws. On December 11, 2014, the Parliamentary Committee on National Security and Administration submitted the Security Laws (Amendment) Bill, 2014 to parliament ${ }^{59}$. The bill consisted of wide ranging amendments to 21 laws. Notable here are Articles 62 through 66 of the bill that amended the National Intelligence Security Act by broadening the powers of security officials. The bill expanded the powers of the National Intelligence Service (NIS) to stop and detain suspects, search and seize private property, and monitor communications without a court warrant. By significantly expanding the powers of intelligence officers, which had been withdrawn in the 1990s after a history of torture of political activists and detention without trial it mobilized the exceptional the securitization of terror as a basis for action. Specifically, Article 18, enables police to extend pre-charge detention for up to 90 days with court authorization, well beyond the 24-hour limit that Kenyan law currently allows. Article 19, allows prosecutors to not disclose evidence to the accused if "the evidence is sensitive and not in the public interest to disclose." Article 62 authorizes NIS officers to "do anything necessary to preserve national security" and to detain people even on suspicion of "engaging in any act or thing or being in possession of anything which poses a threat to national security." Article 66, enables NIS officers to carry out "covert operations," broadly defined as "measures aimed at neutralizing threats against national security." On December $19^{\text {th }} 2014$, the president signed the bill into law.

These speech acts as previously mentioned produced a number of policy shifts, some discussed in this article, under whose cover wide ranging security actions are taken ${ }^{60}$. Core to these policies is the public performance of extrajudicial killings as a symbol of state action. The Independent Medical Legal Unit (IMLU) recorded the following extra-judicial killings in 2014/2015 by city and gender. It is worth noting that these numbers are likely to be an under-estimate. The total number of cases documented by IMLU in 2014 is thirty-four. Out of this number, twenty-nine were male and five female. IMLU further documented extra judicial executions from January to December 2015 with twenty-three male and four female victims. ${ }^{61}$ Unchecked extra-judicial killings contribute to sustaining a narrative of poor, marginalized young men as violent and criminal thereby narrowly viewing their marginality in society as created by crime and not the circumstances that generate violence associated with crime.

The regime instead of addressing the dynamics that increase socioeconomic inequalities across groups, uses police brutality, which leads to a selffulfilling prophecy of young poor men in the margins of Nairobi as a problem and a target of (in)security ${ }^{62}$. This criminalizing has an impact on the production of gender relations in these communities. The relationship between the police and marginalized communities such as those in Eastleigh is one based on mistrust 
and extortion ${ }^{63}$. This means that the police are generally unavailable to respond to crimes in these communities, instead they are viewed as a source of crime. By securitizing terror post-Westgate and Somalis, the state defined a hierarchy of violence. Complimenting this underlying logic of violence is the performance of militarized masculinity by President Uhuru Kenyatta. This is a development that serves the pursuit of military symbols as reflective of control, order and authority. As a civilian head of state providing civilian oversight to the military, Mr. Kenyatta's insistence on wearing full military fatigues when attending military functions and/or visiting Somalia is at odds with military code of conduct regarding civilians wearing military uniforms. Uniforms in general and military uniform in particular, serve a specific function in a context where the military is the ultimate symbol of the monopoly of the means of violence. The military uniform reflects order and discipline, and calls for subordination by displaying a variety of insignia, including badges that indicate rank and emphasize the hierarchical structure of armies. The uniform through differentiation is intended to ensure respect and fear and symbolizes strength and power. Most military uniforms include features designed to make its wearer appear broader or taller, and thus to enhance the soldiers' stature in the eyes of comrades, civilians and the enemy ${ }^{64}$.

Uhuru Kenyatta's periodic appearance in full military gear particularly when in conversation with the nation on Al Shabaab or security related matters serves two main purposes. The first purpose is to project militarized masculinity in order to enable a larger conversation about safety, security and control amongst sections of his supporters. The second is a discursive continuity of securitization speech acts that link assertions about the risk that young Somali men pose to the security of the nation. This is evident in the distinction made between the President speaking as a civilian leader and when he speaks as the commander in chief of the armed forces and therefore wielding legitimate control over the use of force. The context within which securitisation speech acts occur link Al Shabaab, Somali identity and policy responses around Somali securitisation therefore positions this particular act as a projection of ruling masculinity. The relationship between this performance of ruling masculinity and young Somali men in this instance, who are targeted by security sweeps, reprises the historical relationship between Somalis and various regimes. A relationship that has been characterised by violence and surveillance as the primary way in which discussions about Somali positionality is negotiated with the Kenyan state. Ratele's variables of analysis of age and income are critical here because while there is a generic articulation of "Somalis" as a problem Somali elite are not targeted and neither are young Somali men who come from fairly affluent backgrounds affected by securitisation. The combination of age and class dynamics are critical here to understanding why ruling militarise masculinity becomes an important part of the discursive construction of young, poor Somali men as non-hegemonic. The President's military dress is a 
performative ritual act that is designed to communicate authority, demand respect in an environment in which the average Kenyan believes that his government's control on security matters is shaky at best ${ }^{65}$. It also centres a narrative about national security and territoriality that is anchored in military imagery and its institutional power.

\section{Conclusion}

As noted at the beginning of this article, the Kenyan case study offered an opportunity to situate the duality theorized by securitisation scholars namely speech acts by powerful security actors as a securitisation move that leads to extraordinary often extra-judicial measures around an issue and the securitization of identity, which in this case is linked to what was obviously a security question - terror. Securitisation theorists argue that it is not enough for a speech act naming an existential threat to occur but that it has to be accompanied by acceptance from an audience. The securitisation of violent extremism and the accompanying process of legitimizing Somalis as targets postWestgate, demonstrate the centrality of coercion and legitimate fear of violence from external, faceless attackers - Al Shabaab - to mobilise broad based public sentiment towards the inevitability of force. The relationship between speech acts by the President in this case, reinforced through other institutions with legal capabilities such as parliament, coerce acceptance by an audience in this case the Kenyan public. Coercion relies not only on the exceptional nature of the threat identified, which in this case is violent extremism but also on the abrogation of systems of power to mobilise said support. In paying attention to how discourses, speech acts evolve, this article moves beyond the use of legal means and the clear fact of violent extremism as a security issue, as the only basis on which exceptionalism and securitisation is instituted. It expands on securitisation of identity by examining how military and security outcomes are generated by supporting discourses that sustain the balkanisation of historically excluded geographical zones and communities. To do this, the regime reproduces troops and war as ways to rally citizens around the war effort and the "enemy" draws on nationalistic dimensions that involve linking ruling militarized masculinity to honour, respectability and safety. Ruling masculinities in Kenya circle around confrontation, rather than knowledge which is illustrated in the mobility that terror narratives have in enabling the regime to securitise, ghettoise and criminalise non-hegemonic Somali masculinities.

Securitisation acts rely on an element of supra-legality that allows the Executive to abrogate power to the exclusion of other arms of government. Kenya's history with an over-centralised presidential system which was overhauled with the re-entry of multi-party politics in 1992, situates the exceptionalism required by the current regime to address violent extremism in the realm of freedom reversals. However, as has been noted in this article the 
legibility of Somali lives has always been securitised. However, the moments analyses in this article demonstrate that terror has not only provided room to resecuritise Somalis but also rendered it a threat and threatened its survival through policy responses that geographically and physically target them as part of dealing with terror. There are tensions between those who consider the regime's responses as justifiable routes to dealing with terror and Somalis as collateral damage who have simply been criminalised and those who view the regime's actions as a deliberate - even if not named as such - assault on Somalis as a nation. The inconsistency in security speech acts that oscillate between asserting that policy responses are not about Somalis and their actions demonstrating the opposite as seen in \#KasaraniConcentrationCamp do not illustrate the absence of a securitising move on Somalis. Rather, it points to the mobility and ambiguity of security policies developed to deal with terrorism. The ambiguity is occasioned by the position that terrorism is not a religious or a community specific problem but one that is more agile and thrives on societal cleavages. The inability of the state to deal with this agility has resulted in responses that target the "low hanging fruit". In Kenya, these responses have gone with the obvious threat of Al Shabaab in neighbouring Somali and the assumption that there are identity based loyalties from Somalis everywhere ${ }^{66}$. As argued in the article these securitising moves on societies have gendered ramifications that entrench exclusion rather enable long-term possibilities of desecuritisation.

This article also draws attention to the referent object in securitisation processes, which is often the state and entities that are able to substantively produce themselves as security actors. The inability of the Somali nation in Kenya to produce itself as a security actor facing an existential threat means their experience of the securitization process is rendered normal. Consequently, this powerlessness combined with the securitisation of their identity results in the deliberate identification of non-hegemonic Somali men as targets to be dealt with as part of the larger security threat identified by the state. In this instance, extraordinary circumstances utilized by the regime due to violent extremism also exercises the right to take life and/or rob individuals of their humanity. The use of targeted violence, incarceration and management of inner city boundaries as explored in this article become useful tools to achieve these goals. ${ }^{67} \mathrm{By}$ drawing attention to the people at the centre of a securitisation narrative, I move away from the abstract object - the state - as the target of an existential threat, to an analysis of threatened identities and therefore new regimes of masculinities produced by terror discourses. It enables an expansion of what we conceptually consider the "objects" that can face an existential threat and generate sufficient authority to securitise the source of the threat.

\section{Notes}


1 Douglas, Purity and Danger

2 See Society for International Development. Exploring Kenya's Inequalities

${ }^{3}$ Douglas, Purity and Danger, 156

4 Ibid

5 See Douglas, Purity and Danger; Kandiyoti, "Identity and its Discontents" 2002, 172

${ }^{6}$ See Ratele, "Analysing Males in Africa: Certain Useful Elements in Considering Ruling

Masculinities"

${ }^{7}$ Buzan, Ole Wæver and Jaap de Wilde. Security: A New Framework for Analysis

8 Ibid

${ }^{9}$ Huysman, 2011: 371

10 Buzan and Waever, 2009:261

11 Ibid

12 Mutavi. "IPOA to observe transparency in probe into Eastleigh killing".

13 Ibid

${ }^{14}$ I conducted a social media analysis to assess citizen's perceptions of the regimes responses to security related matters. I used Alexa ranking to select the ten most visited news websites in Kenya and those with social media integration that is, those with Facebook and Twitter accounts. The trend analysis was used to assess citizen responses to Kasarani Concentration Camp.

15 See KNCHR, An Identity Crisis?; Amnesty International, Somalis are Scapegoats in Kenya's counter-terror crackdown

${ }^{16}$ See Castagno, "The Somali-Kenyan Controversy"; Turton, "Somali Resistance to Colonial Rule"

${ }^{17} \mathrm{KNCHR}$, An Identity Crisis?", 80

18 KNHRC, "An Identity Crisis?", 22; TJRC, "Report of the Truth Justice and Reconciliation

Commission", 12-13

${ }^{19}$ See TJRC, "Report of the Truth Justice and Reconciliation Commission", Vol 4.

20 KNCHR, "An Identity Crisis?" 34-35

${ }^{21}$ See TJRC, "Report of the Truth Justice and Reconciliation Commission"

${ }^{22}$ See KNCHR, "The Error of Fighting Terror with Terror"

23 The Islamic Court Union (ICU) was a loose formation of Islamic judicial systems created in mid2004 that managed to restore some sort of civil order after years of a violent anarchy in Somalia and received significant support from the Somali people. ICU had taken over most of southern Somalia in the second half of 2006 and was in direct opposition to the Transitional Federal Government that was more palatable to actors internally and in the sub-region. Al Shabaab was the militant wing of the ICU. In December 2006 and January 2007, Somali government and Ethiopian forces supported by the international actors rooted out the Islamic Court Union formation but the radical Al Shabaab retreated into the South. See, Wise, "Al Shabaab"

${ }^{24}$ Huff, A., Dowd, C., Okech, A., Muteru, A., Shahrokh, T., Zadi Zadi, P., Alidu, S.M. and Allouche, J. Violence and Violence Reduction Efforts in Kenya, Uganda, Ghana and Ivory Coast

${ }^{25}$ National Consortium for the Study of Terrorism and Responses to Terrorism. "Al-Shabaab Attack on Westgate Mall in Kenya", 2

${ }^{26}$ See Botha, "Assessing the vulnerability of Kenyan youths to radicalisation and extremism"; ICG, "Kenya: Al Shabaab - Closer to Home".

27 Ibid

${ }^{28}$ Wahito, "Uhuru mourns nephew killed in Westgate attack"

${ }^{29}$ See SID, Exploring Kenya's Inequality:?"

${ }^{30}$ Kenya's history with remote violence can be traced back to the first bus park attack in 1975 and escalated in 1998 with the Al Qae'da attack on the United States embassies in Nairobi and Dar es Salaam.

31 These inequalities were evident protests which begun with a divisive election mobilized largely around the International Criminal Court charges against the President Uhuru Kenyatta and his deputy William Ruto. These included, but were not limited to, civil society protests around increases in Member of Parliament salaries, national protests against the imposition of Value Added Tax (VAT) on basic food items such as flour, a 24-day teachers strike on salaries, a protest around the non-prosecution of a young girl who was raped and thrown into a pit latrine in rural Kenya and a three-week strike by medical personnel over wage disputes and poor working conditions. See Article 19, “Country Report: Protest in Kenya 2015”, Herbling, "Kenyan 
legislators emerge second in global pay ranking". Kenyan members of parliament are ranked as the second highest paid globally

32 See Okwembah, 2013

33 Buzan et al., 1998:119

34 See Eckstein, Harry 1992.

35 Okech, 2013: 39

${ }^{36}$ See Presidential Strategic Communications Unit. 2013.

37 See Kenya National Assembly Official Report 14th April, 2015

38 See Daily Nation Editorial, 2014.

39 See Kenya National Assembly. 2013.

40 See Stevis, 2015 and Gitau, 2015

41 See Presidential Strategic Communications Unit. 2014.

${ }^{42}$ Independent Policing Oversight Authority. 2014. "Monitoring Report on Operation Sanitization Eastleigh".

43 Ibid

${ }^{44}$ Amnesty International, Somalis are Scapegoats in Kenya's counter-terror crackdown

45 Ibid

46 Ibid

47 See Kandiyoti, "Identity and its discontents"

48 Stevis, "Kenyan Money-Transfer Ban Puts Strain on Somalis"

${ }^{49}$ KNCHR, An Identity Crisis?"

50 Social media analysis conducted for this article

51 Karimi, "UNSCR 2242 \& The Role of Women in Countering Violent Extremism".

52 Mahiri, Violent Extremism and Community Resilience

53 Daily Nation. "The rise of women in terrorism"

54 See Amnesty International, 2014

${ }^{55}$ KNCHR, An Identity Crisis?"

56 See IPOA, 2014; Star Kenya, 2014

57 See Al Jazeera, 2016

58 See Kenya National Assembly Official Report 14th April, 2015

${ }^{59}$ See Security Laws (Amendment) Bill 2014

60 Daily Nation, "Uhuru orders KWS, Prisons and NYS be put under IG Kimaiyo"

61 See IMLU, "Report on Deaths from Police Bullets from January To December 2015".

62 Ibid.

63 Kenya National Assembly Official Record, 598

64 See Pfanner. "Military uniforms and the law of war", 94

65 Daily Nation, "Mr. President, get your act together this year"; Standard Reporter. 'Nation' sacks Dennis Galava over editorial critical of President Uhuru"

66 See Daily Nation, 2015

67 Foucault, Society Must Be Defended

${ }^{67}$ See Joint Parliamentary Report, 2013, Kenya National Assembly Official Record, 2013, 2015

\section{BIBLIOGRAPHY}

Aljazeera. "Is Kenya losing the war against Al Shabaab - Interview with Kenya's Foreign Minister Amina Mohamed".

http://www.aljazeera.com/programmes/upfront/2016/10/kenya-losing-war-alshabab-161007124819672.html. October 7, 2016

Amnesty International, Somalis are Scapegoats in Kenya's counter-terror crackdown. London. Amnesty International. 2014

Article 19, "Country Report: Protest in Kenya 2015". https://www.article19.org/resources.php/resource/38331/en/country-report:protest-in-kenya-2015. 2016 
Botha, Anneli, "Assessing the vulnerability of Kenyan youths to radicalisation and extremism", ISS Paper 245, pp 1-28. 2013

Buzan, Barry, Ole Wæver and Jaap de Wilde. Security: A New Framework for Analysis, Boulder, CO: Lynne Rienner. 1998

Buzan, Barry. \& Waever, Ole. "Macrosecuritisation and security constellations: reconsidering scale in securitisation theory". Review of International Studies, 35, pp.253276. 2009

Castagno, A. A, "The Somali-Kenyan Controversy: Implications for the Future", Journal of Modern African Studies, Vol 2, pp 165-188. 1964

Cherono, Stella and Kamau, Wanderi. "Uhuru Kenyatta unveils 525 police vehicles at Uhuru Park”. Daily Nation January 16, 2017.

Daily Nation. "The rise of terrorism". http://www.nation.co.ke/lifestyle/lifestyle/Therise-of-women-in-terrorism/1214-3384688-b7cl9f/. September 17, 2016

Daily Nation, "Mr President, get your act together this year" http://www.nation.co.ke/oped/Editorial/Mr-President-get-your-act-together-thisyear/440804-3018414-ura24c/index.html. January 1, 2016

Daily Nation. "Duale in tight spot over Shabaab attack and his 30-day list". http://www.nation.co.ke/news/politics/Duale-in-tight-spot-over-Shabaab-attack-andhis-30-day-list/1064-2682974-c0hmom/index.html. April 11, 2015

Daily Nation, "Uhuru orders KWS, Prisons and NYS be put under IG Kimaiyo". http://mobile.nation.co.ke/news/Uhuru-orders-KWS-and-Prisons-and-NYS-be-putunder-IG-Kimaiyo/1950946-2357538-format-xhtml-. June 21, 2014

Daily Nation Editorial, "Straight answers needed in MPs' Westgate probe" http://mobile.nation.co.ke/blogs/Straight-answers-needed-in-MPs-Westgateprobes/1949942-2160634-format-xhtml-1186ri0/index.html January 25, 2014

Douglas, Mary. Purity and Danger: An Analysis of the Concepts of Pollution and Taboo. London: Routledge. 2002

Eckstein, Harry. "Rationality and Frustration" In Harry Eckstein, ed., Regarding Politics: Essay on Political Theory, Stability and Change. Berkeley: University of California Press. 1992

Foucault Michel., Society Must Be Defended: Lectures at the Collège de France, 1975-76, translated by David Macey, London: Penguin. 2004.

Gitau, Paul. "Building of Kenya-Somalia border wall begins". East African Standard https://www.standardmedia.co.ke/article/2000158488/building-of-kenya-somaliaborder-wall-begins April 16th 2015

Government of Kenya, The Security Laws (Amendment) Bill. Nairobi. 2014 
Huff, Amber., Dowd, C., Okech, A., Muteru, A., Shahrokh, T., Zadi Zadi, P., Alidu, S.M. and Allouche, J. "Violence and Violence Reduction Efforts in Kenya, Uganda, Ghana and Ivory Coast: Insights and Lessons towards Achieving SDG 16". IDS Evidence Report 210. Institute of Development Studies. Brighton. 2016

Huysmans, Jeff. "What's in an act? On security speech acts and little security nothings" Security Dialogue 42(4-5) 371-383. 2011

International Crisis Group. "Kenya: Al Shabaab - Closer to Home", Africa Briefing, No 102, pp 1-20. 2014

Independent Medico Legal Unit, "Report on Deaths from Police Bullets from January To December 2015". http://www.imlu.org/2011-06-30-23-44-4/2011-08-04-18-0626/news/item/122-report-on-deaths-from-police-bullets-from-january-to-december2015.html

Independent Policing Oversight Authority. "Monitoring Report on Operation Sanitization Eastleigh Publically Known as "Usalama Watch". 2014

Kandiyoti, Deniz. 'Identity and its discontents: Women and the nation.' Millennium: Journal of International Studies 20(3): 429-43. 1991

Karimi, Vicky. "UNSCR 2242 \& The Role of Women in Countering Violent Extremism". http://blog.giwps.georgetown.edu/unscr-2242-the-role-of-women-in-counteringviolent-extremism/. November 18, 2015

Kenya Law Reform Commission. "Security Law Amendment Act Ruling". http://www.klrc.go.ke/index.php/media-center/523-security-law-amendment-actruling n.d

Kenya National Assembly. Report of The Joint Committee on Administration and National Security; and Defence and Foreign Relations on The Inquiry into The Westgate Terrorist Attack, and Other Terror Attacks in Mandera in North-Eastern and Kilifi in The Coastal Region. Nairobi. 2013

Kenya National Assembly Official Record (Hansard). 17th April 2002

Kenya National Assembly Official Record (Hansard). 26th March 2014

Kenya National Assembly Official Record (Hansard). 27th August, 2014

Kenya National Assembly Official Record (Hansard). 2nd April 2015

Kenya National Assembly Official Record (Hansard). 14th April 2015

Kenya National Human Rights Commission (KNHRC). "An Identity Crisis? A Study on the Issuance of National Identity Cards in Kenya”, Nairobi. KNHRC. 2007

Mahiri, Elizabeth. "Violent Extremism and Community Resilience". Rift Valley Institute Meeting Report, 2016 
Mbugua wa Mungai and David A. Samper "No Mercy, No Remorse": Personal Experience Narratives about Public Passenger Transportation in Nairobi, Kenya. Africa Today Vol. 52, No. 3 (Spring, 2006), pp. 51-81

National Consortium for the Study of Terrorism and Responses to Terrorism. "AlShabaab Attack on Westgate Mall in Kenya".

https://www.start.umd.edu/sites/default/files/publications/local attachments/START BackgroundReport alShabaabKenya Sept2013.pdf. 2013

National Youth Service; http://nys.go.ke/public/content/item/135/ACHIEVEMENTSOF-THE-NATIONAL-YOUTH-SERVICE-IN-LINE-WITH-THE-5-POINT-

VISION\#sthash.N8iCYrHX.dpuf;

Okech, Awino. "Dealing with Asymmetrical Conflict: Lessons from Kenya" in Special Issue of Strategic Review of Southern Africa, 1/2015

Okech, Awino. "Gendered Security: Between Ethno-nationalism and Constitution Making". African Peace and Conflict Journal. 2013

Okwembah, Arthur. "\#weareone - How Westgate united Kenyans". BBC Africa, Nairobi http://www.bbc.co.uk/news/world-africa-24305277. September 272013.

Ombati, Cyrus. "Suspects on police radar for financing Al Shabaab terrorists" Read more at: https://www.standardmedia.co.ke/article/2001227652/suspects-onpolice-radar-for-financing-al-shabaab-terrorists. January 302017

Pfanner, Toni. "Military uniforms and the law of war". RICR Mars IRRC Vol. $86 \mathrm{~N} 853$. https://www.icrc.org/eng/assets/files/other/irrc 853 pfanner.pdf. March 2004

Plural Security Insights. Hustling for Security: Managing plural security in Nairobi's poor urban settlements. Amsterdam. Plural Security Insights. 2016

Presidential Strategic Communications Unit. "Full statement of President Uhuru Kenyatta on terror attack" https://www.standardmedia.co.ke/article/2000094033/fullstatement-of-president-uhuru-kenyatta-on-terror-attack. September 22 2013

Presidential Strategic Communications Unit. "President Uhuru Kenyatta State of the Nation Address (full speech)"

https://www.kenya-today.com/news/read-president-uhuru-kenyatta-state-unionaddress-full-speech. March 27th, 2014

Ratele, Kopano. "Analysing Males in Africa: Certain Useful Elements in Considering Ruling Masculinities” African and Asian Studies 7 (2008) 515-536

Society for International Development (SID). Exploring Kenya's Inequality: Pulling Apart or Pooling Together. SID. 2014

Star Kenya. "Somalis Detained in Squalor at Kasarani". https://www.facebook.com/thestarkenya/photos/a.452805321431373.99315.224865 787558662/737219709656598/. April 16, 2014 
Standard Reporter. 'Nation' sacks Dennis Galava over editorial critical of President Uhuru". East African Standard:

https://www.standardmedia.co.ke/article/2000188815/nation-sacks-dennis-galavaover-editorial-critical-of-president-uhuru. January $21^{\text {st }} 2016$

Stevis, Matina. "Kenyan Money-Transfer Ban Puts Strain on Somalis" Wall Street Journal. https://www.wsj.com/articles/kenyan-money-transfer-ban-puts-strain-on-somalis1429053973. April 14, 2015

Turton E R. "Somali Resistance to Colonial Rule and the Development of Somali Political Activity in Kenya 1893-1960", The Journal of African History, Vol 13, pp 119-143. 1971

Truth Justice and Reconciliation Commission (TJRC), "Report of the Truth Justice and Reconciliation Commission - Vol 1V". Nairobi: TJRC. 2013

Yuval-Davis, Nira and Anthias, Flora (eds). Women-Nation-State London: Macmillan. 1989

Williams. Zoe. "The radicalisation of Samantha Lewthwaite, the Aylesbury schoolgirl who became the 'white widow'"

https://www.theguardian.com/uk-news/2014/jun/27/what-radicalised-samanthalewthwaite-77-london-bombings 27th June 2014 